\title{
Strätlingite: compatibility with sulfate and carbonate cement phases
}

\author{
M. U. Okoronkwo $\mathbb{D}$ F. P. Glasser
}

Received: 24 June 2015/ Accepted: 26 October 2015/Published online: 30 October 2015

(C) RILEM 2015

\begin{abstract}
The silicate AFm, strätlingite, has been shown to be stable in high aluminosilicate cement systems but its stability with respect to the anion content of hydrated Portland cement paste is unknown. The stability of strätlingite in the presence of sulfate and carbonate phases relevant to cement systems are reported. Results show that strätlingite persists at the sulfate activity conditioned by gypsum, ettringite and at carbonate activity conditioned by the presence of calcite, carbonate AFm, or carbonate AFt. Structural incorporation of anions such as carbonate or sulfate in strätlingite was not observed in the temperature range $20-85{ }^{\circ} \mathrm{C}$.
\end{abstract}

Keywords Strätlingite $\cdot$ Sulfate $\cdot$ Carbonate . Stability $\cdot$ Compatibility

\begin{tabular}{ll}
\multicolumn{2}{l}{ Abbreviations } \\
ST & Strätlingite \\
SHG & Siliceous hydrogarnet \\
C-S-H & Calcium silicate hydrate
\end{tabular}

M. U. Okoronkwo $(\bowtie) \cdot$ F. P. Glasser

Department of Chemistry, University of Aberdeen,

Meston Building, Meston Walk, Old Aberdeen,

Scotland AB24 3UE, UK

e-mail: muokoronkwo@gmail.com

M. U. Okoronkwo

Department of Chemistry, Abia State University, P.M.B.

2000, Uturu, Abia State, Nigeria

$\begin{array}{ll}\mathrm{Cc} & \text { Calcite } \\ \mathrm{CO}_{3}-\mathrm{AFm} & \mathrm{C}_{4} \mathrm{AcH}_{11} \\ \mathrm{CO}_{3}-\mathrm{AFh} & \mathrm{C}_{4} \mathrm{Ac}_{0.5} \mathrm{H}_{12} \\ \mathrm{SO}_{4}-\mathrm{AFm} & \mathrm{C}_{4} \mathrm{AsH}_{12} \\ \text { ETT } & \text { Ettringite }\left(\mathrm{SO}_{4} \text {-AFt, } \mathrm{C}_{6} \mathrm{As}_{3} \mathrm{H}_{32}\right) \\ \mathrm{CO}_{3} \text {-AFt } & \mathrm{C}_{6} \mathrm{Ac}_{3} \mathrm{H}_{32} \\ \mathrm{GYP} & \mathrm{Gypsum} \\ \mathrm{CH} & \mathrm{Ca}(\mathrm{OH})_{2}\end{array}$

\section{Introduction}

It is a common practice to add gypsum to Portland cement [21]. Also, most novel cements such as the calcium aluminosulfate cements contain substantial amounts of sulfate. Cement could also be blended with limestone, mainly $\mathrm{CaCO}_{3}$, and atmospheric $\mathrm{CO}_{2}$ is readily uptaken by wet cements pastes cured in the open. In this way, sulfate and carbonate phases form normally in the hydration process of cement paste. We know that $\mathrm{AFm}$ and $\mathrm{AFt}$ are common sulfate and carbonate bearing phase product of cement hydration. High saturation in sulfate -rich service environments and elevated temperature may also lead to the formation of gypsum and calcite. The impact of these sulphur and carbon bearing phases on the stability of the crystalline phases occurring in the $\mathrm{CaO}-\mathrm{Al}_{2} \mathrm{O}_{3}-$ $\mathrm{SiO}_{2}-\mathrm{H}_{2} \mathrm{O}$ system is important as reactive supplementary materials are often added with the result that 
the composition of the reactive fraction of concrete varies over wide limits of composition.

Thermodynamic data has shown that the constitution of minor phases, AFm and AFt is very sensitive to temperature and the activity of anions, especially $\mathrm{CO}_{3}{ }^{2-}, \mathrm{SO}_{4}{ }^{2-}$ and $\mathrm{OH}^{-}$, and that the resulting distribution of anions is temperature dependent over short temperature ranges, examples are given in the range $0-40{ }^{\circ} \mathrm{C}$ by Matschei and others $[4,13,14]$.

Strätlingite has the same basic layer structure as other AFm phases with a positively charged layer, $\mathrm{Ca}_{2} \mathrm{Al}$ $(\mathrm{OH})_{6}^{+}$which is charge balanced by an interlayer anion and space filled by a content on neutral water molecules. In strätlingite, the anion is believed to be an aluminosilicate $\left[\mathrm{AlSi}\left(\mathrm{O}_{8} \mathrm{H}_{8}\right) \cdot 0.25 \mathrm{H}_{2} \mathrm{O}\right]^{-}$, Fig. 1, after Rinaldi et al. [19]. AFm phases can thus accommodate a wide range of anions in the interlayer amongst which are $\mathrm{SO}_{4}^{2-}, \mathrm{CO}_{3}^{2-}, \mathrm{OH}^{-}$, and $\mathrm{Cl}^{-}$. Theoretically, it might be expected that strätlingite will behave like other AFm phases and undergo a range of anion substitutions, but our knowledge in this regard is limited. Data are presented on the phase relation of strätlingite with gypsum, calcite, and the sulfate and carbonate AFm and AFt phases commonly observed in Portland and blended Portland cement compositions.

\section{Experimental}

\subsection{Analytical methods}

Mineralogical examinations of dried solids were by X-ray Powder Diffraction (XRD) using a Bruker D8
Advance X-Ray Powder Diffractometer with $\mathrm{CuK} \alpha$ radiation. The angular scan was between 5 and $45^{\circ} 2 \theta$ with a step size of 0.02 and count time of $1 \mathrm{~s}$ per step. XRD patterns were collected at laboratory temperature of $\sim 20{ }^{\circ} \mathrm{C}$. Infrared spectra of samples were collected by the Attenuated Total Reflection, ATR method with PerkinElmer UATR Spectrometer equipped with a diamond cell. Measurements were collected in the mid-infrared region $400-4000 \mathrm{~cm}^{-1}$ at a resolution of $4 \mathrm{~cm}^{-1}$. The morphology of selected samples was examined with a Hitachi S-520 Scanning Electron Microscope (SEM). A voltage of $20 \mathrm{kV}$ was applied across the tungsten filament electron gun. Selected samples where ground to fine powder and a thin layer was collected on the brass sample holder and gold coated with an Emscope SC-500A sputter coater to prevent charging or overheating.

\subsection{Sample preparation and reactions}

Strätlingite was synthesized according to the protocol reported by $[13,15]$ from a stoichiometric mixture of $\mathrm{CaO}, \mathrm{NaAlO}_{2}$ and $\mathrm{Na}_{2} \mathrm{SiO}_{3} \cdot 5 \mathrm{H}_{2} \mathrm{O}$.

Ettringite $\left(\mathrm{SO}_{4}-\mathrm{AFm}\right), \mathrm{Ca}_{6} \mathrm{Al}_{2}\left(\mathrm{SO}_{3}\right)_{3}(\mathrm{OH})_{12} \cdot 26 \mathrm{H}_{2}$ O: Synthesized according to Matschei et al. [15] and Matschei [13]. A slurry of stoichiometric amounts of $\mathrm{NaAlO}_{2}, \mathrm{Na}_{2} \mathrm{SO}_{4}$ and $\mathrm{CaO}$ (obtained from $\mathrm{CaCO}_{3}$ heated at $1000{ }^{\circ} \mathrm{C}$ for $\sim 12 \mathrm{~h}$ ) in $10 \mathrm{w} / \mathrm{v}$ sucrose solution, liquid/solid $\sim 10$, was stirred for 3 days and left to age at room temperature $22{ }^{\circ} \mathrm{C}$ in HDPE bottle for 4 weeks before filtration. The sample was flushed several times with degassed deionized water. Alternatively, ettringite was prepared from slurry of 1:3

Fig. 1 Structure of strätlingite: $\mathrm{Ca}_{2} \mathrm{Al}(\mathrm{AlSi}) \mathrm{O}_{2}(\mathrm{OH})_{10}$ $\cdot 2.25 \mathrm{H}_{2} \mathrm{O}$ [19]: (blue balls $=\mathrm{Ca}$; pale bluegreen $=\mathrm{O}, \mathrm{OH} ;$ red $=\mathrm{Al}$, $\mathrm{Si}$; small pale yellow ball $=\mathrm{H}_{2} \mathrm{O}$ ). Drawn with ATOMS V6.4.1 [20] using data from Rinaldi et al. [19]. (Color figure online)

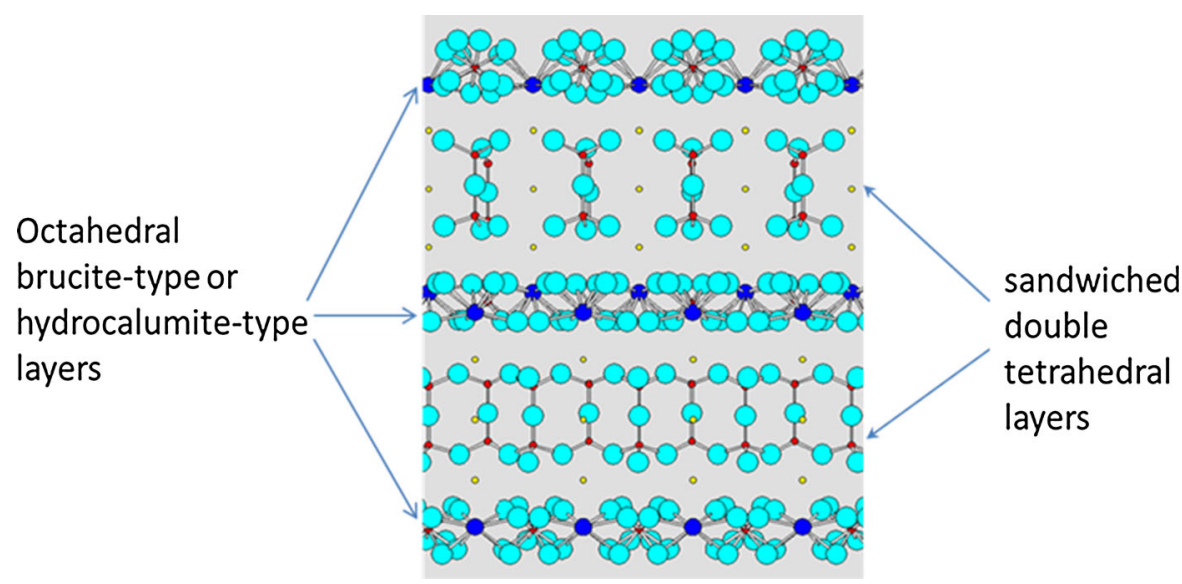


Fig. 2 The two compartment experimental set up: previously illustrated [18]

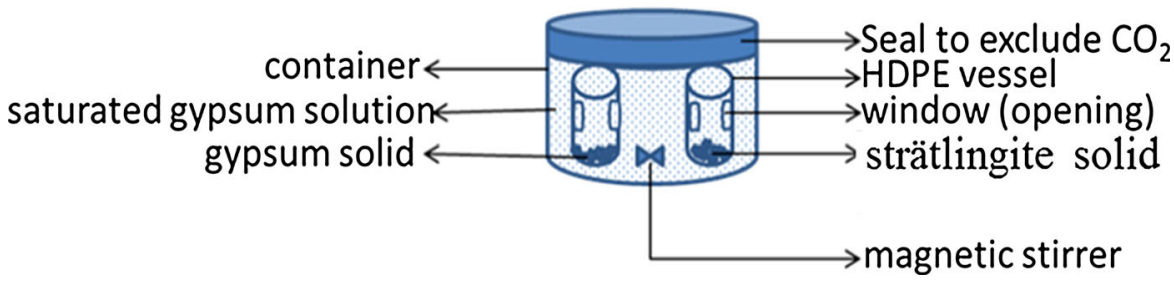

molar ratios of $\mathrm{C}_{3} \mathrm{~A}$ and $\mathrm{CaSO}_{4} \cdot 2 \mathrm{H}_{2} \mathrm{O}$ in degassed deionized water. The w/s ratio was adjusted to $\sim 20$ and the mixture was stirred for 2 weeks at room temperature $\left(20 \pm 2{ }^{\circ} \mathrm{C}\right)$.

$\mathrm{CO}_{3}$-AFt, $\mathrm{Ca}_{6} \mathrm{Al}\left(\mathrm{CO}_{3}\right)_{3}(\mathrm{OH})_{12} \cdot 26 \mathrm{H}_{2} \mathrm{O}$, was synthesized from a stoichiometric mixture of $\mathrm{CaO}, \mathrm{NaAlO}_{2}$ and $\mathrm{Na}_{2} \mathrm{CO}_{3}$ in a $10 \% \mathrm{w} / \mathrm{v}$ sucrose solution according to the modified Carlson and Berman method used elsewhere [13, 15]. Previously prepared slurries of sodium aluminate and sodium carbonate were mixed with $10 \%$ w/v sucrose- $\mathrm{CaO}$ mixture, stirred for 3 days and then aged with periodic agitation at room temperature $20 \pm 2{ }^{\circ} \mathrm{C}$ for 2 weeks before filtration and washing. Matschei [13] has shown that when well washed, the product is sucrose-free.

$\mathrm{SO}_{4}-\mathrm{AFm}, \mathrm{Ca}_{4} \mathrm{Al}_{2} \mathrm{SO}_{4}(\mathrm{OH})_{12} \cdot 6 \mathrm{H}_{2} \mathrm{O}$, was prepared according to previous protocol $[13,15]$, by mixing $\mathrm{C}_{3} \mathrm{~A}$ and $\mathrm{CaSO}_{4}$ in a 1:1 molar ratio, slurried in boiling ultra pure water and thereafter cured at $85{ }^{\circ} \mathrm{C}$ for two weeks in PTFE bottles prior to filtration.

$\mathrm{CO}_{3}-\mathrm{AFm}, \mathrm{Ca}_{4} \mathrm{Al}_{2} \mathrm{CO}_{3}(\mathrm{OH})_{12} \cdot 5 \mathrm{H}_{2} \mathrm{O}$, was prepared according to prvious protocol $[13,15]$, by mixing previously prepared $\mathrm{C}_{3} \mathrm{~A}$ and $\mathrm{CaCO}_{3}$ in a $1: 1$ molar ratio with previously degassed ultra pure water (w/ $\mathrm{s} \sim 10$ ) at $25^{\circ} \mathrm{C}$ and stored with agitation in HDPEbottles for two weeks prior to filtration.

\subsubsection{Strätlingite-gypsum phase relations}

Single compartment experiment Mixtures of strätlingite and gypsum $\mathrm{CaSO}_{4} \cdot 2 \mathrm{H}_{2} \mathrm{O}$ were slurried in degassed deionized water and reacted at 20,55 and $85^{\circ} \mathrm{C}$ for 4 weeks in PTFE bottles with periodic agitation. The mixture was prepared with a target of achieving a $10 \%$ substitution for $(\mathrm{OH})$ i.e. sufficient sulfate to form $\mathrm{Ca}_{2} \mathrm{Al}_{2} \mathrm{SiO}_{2}\left(\mathrm{SO}_{4}\right)_{0.5}(\mathrm{OH})_{9} \cdot 2.25 \mathrm{H}_{2} \mathrm{O}$. Equivalents of $\sim 2 \mathrm{~g} / \mathrm{L}$ excess of gypsum were added to the mixtures respectively. After 4 weeks of ageing, the samples were filtered, dried and characterized by XRD, FTIR and SEM.

Two compartment experiment In order to prevent physical contact of the solid reactants and avoid physical incorporation of the gypsum in the strätlingite, a two component system was adopted. $4 \mathrm{~g}$ of gypsum was dispersed in $1 \mathrm{~L}$ of distilled water and stirred for about 3 days and then filtered. A thin film of $0.3 \mathrm{~g}$ of previously synthesized strätlingite was placed in a HDPE vessel which has been carved into a beaker with double window (opening) just $1.5 \mathrm{~cm}$ above the bottom, Fig. 2. The vessel was then filled up with the filtered saturated solution of gypsum and allowed to stand for about $10 \mathrm{~min}$ for the strätlingite to settle. A second vessel was similarly prepared with $2 \mathrm{~g}$ of solid gypsum placed in it. The two vessels: one containing strätlingite and the other containing gypsum were completely immersed in a plastic tube (internal diameter $12 \mathrm{~cm}$ ) containing the previously prepared gypsum solution. The tube was then sealed and the solution in the tube was stirred with the aid of magnetic stirrer and maintained at $5{ }^{\circ} \mathrm{C}, 20 \pm 2{ }^{\circ} \mathrm{C}$. A third set was kept at $55^{\circ} \mathrm{C}$ and shaken at 60 strokes per minute. The small vessels are about $3.5 \mathrm{~cm}$ in diameter and were separated by $\sim 4 \mathrm{~cm}$. The second vessel containing 2 g gypsum was placed to provide the excess gypsum that will maintain saturation should any sulfate be uptaken by the solid as reaction proceeds. The ongoing saturation was confirmed by ion chromatographic analysis of the aqueous phase. After selected reaction time intervals, the products were filtered, dried in desiccators containing silica gel at room temperature, $20 \pm 2{ }^{\circ} \mathrm{C}$, and characterized by XRD. The gypsum solutions were replaced with fresh solutions at the start of each new interval.

The solution was stirred with the aid of a magnetic stirrer for the set-ups at $5{ }^{\circ} \mathrm{C}$ and $20 \pm 2{ }^{\circ} \mathrm{C}$ and by 
shaking at the rate of 60 strokes/min in a water bath for the set up at $55^{\circ} \mathrm{C}$.

\subsubsection{Strätlingite-calcite phase relations}

Similar experiments as described in Sect. 2.2.1 were repeated with calcite in place of gypsum.

\subsubsection{Strätlingite: AFt phase relations}

A 1:1 molar mixture of strätlingite and $\mathrm{SO}_{4}$-AFt was slurried in degassed deionized water and aged at 20, 55 and $85{ }^{\circ} \mathrm{C}$ in HDPE/PTFE bottles for 4 weeks with periodic agitation. Thereafter, the sample were filtered and characterised by XRD.

Similarly, 1:1 molar mixture of strätlingite and $\mathrm{CO}_{3}$-AFt was slurried in degassed deionised water and aged at 20, 55 and $85^{\circ} \mathrm{C}$ in HDPE/PTFE bottles for 4 weeks with periodic agitation. Thereafter, the sample were filtered and characterised by XRD.

\subsubsection{Strätlingite: AFm phase relations}

A 1:1 molar mixture of strätlingite and $\mathrm{SO}_{4}$-AFm $\left(\mathrm{Ca}_{4} \mathrm{Al}_{2} \mathrm{SO}_{4}(\mathrm{OH})_{12} \cdot 6 \mathrm{H}_{2} \mathrm{O}\right)$ was slurried in degassed deionised water and aged at 20,55 and $85{ }^{\circ} \mathrm{C}$ with periodic agitation for 30 days in HDPE. Filtered and dried product solid was characterised by XRD, FTIR and SEM.

Similarly 1:1 molar mixture of strätlingite and $\mathrm{CO}_{3}$ AFm $\mathrm{Ca}_{4} \mathrm{Al}_{2} \mathrm{CO}_{3}(\mathrm{OH})_{12}$. $5 \mathrm{H}_{2} \mathrm{O}$ was slurried in degassed deionized water and aged at 20, 55 and $85^{\circ} \mathrm{C}$ as in the previous section.

\section{Results and discussion}

3.1 Strätlingite in the presence of sulfate: $20-85{ }^{\circ} \mathrm{C}$

\subsubsection{Strätlingite-gypsum phase relation: $20-85^{\circ} \mathrm{C}$}

The XRD pattern of the resulting solids (Fig. 3a) shows that strätlingite persisted in the presence of gypsum. The resulting phase assemblage was strätlingite, gypsum, and $\mathrm{C}-\mathrm{S}-\mathrm{H}$ at 20,55 and $85^{\circ} \mathrm{C}$. The SEM image (Fig. 4a) of the strätlingite-gypsumwater mixture cured at $55{ }^{\circ} \mathrm{C}$ shows the clear monoclinic gypsum grains dispersed in strätlingite powder,

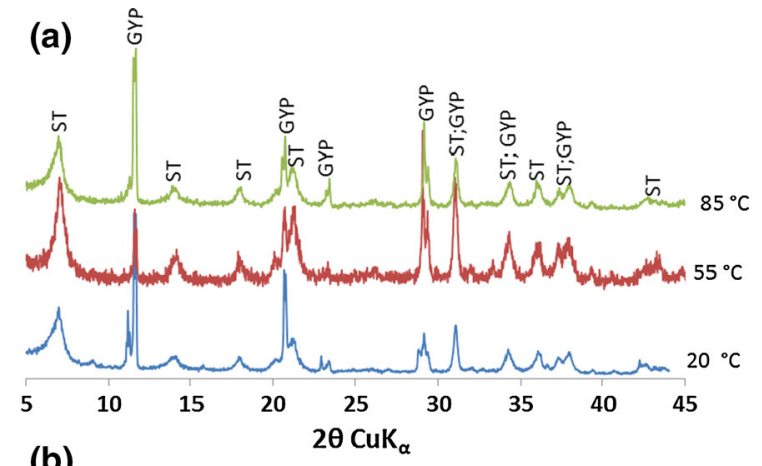

(b)

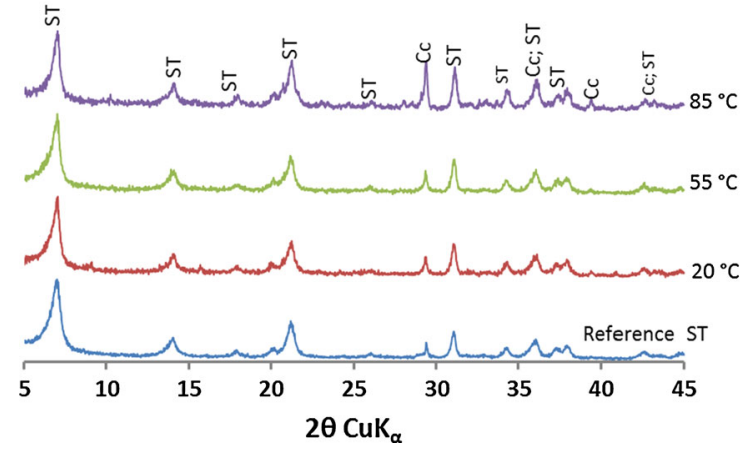

Fig. 3 XRD patterns of the resulting solids from a Strätlingitegypsum slurry cured for 30 days in supersaturated gypsum solution; b Strätlingite cured in saturated gypsum solution for 70 days: strätlingite persisted in the presence of gypsum

suggesting coexistence of both phases, in agreement with the XRD pattern. The solid from the strätlingitegypsum slurry at $85^{\circ} \mathrm{C}$ was analysed by electron microprobe and the result show $<1 \%$ sulphur substitution over about ten random points analysed. The minute amount of sulphur detected in strätlingite may have either occurred as minor substitution or originated from the excess gypsum solid which perhaps has been physically incorporated into the grains of strätlingite.

Further investigation by the two compartment system, first used in Okoronkwo [18], also shows that strätlingite is compatible with gypsum under the range of experimental conditions. Figure $2 b$ presents the XRD pattern of strätlingite cured in saturated gypsum solution for 70 days at $20-85^{\circ} \mathrm{C}$. The IR spectra of the strätlingite sample cured for 70 days in saturated gypsum solution is shown in Fig. 4b. The assignment of the adsorption bands is summarized in Table 1, according to $[9,10,16,22]$. The absorption at $\sim 1065$ and $\sim 1400 \mathrm{~cm}^{-1}$ are assigned to $\mathrm{C}-\mathrm{O}$ vibrations. The minor absorption band between 1035 and $1100 \mathrm{~cm}^{-1}$, 


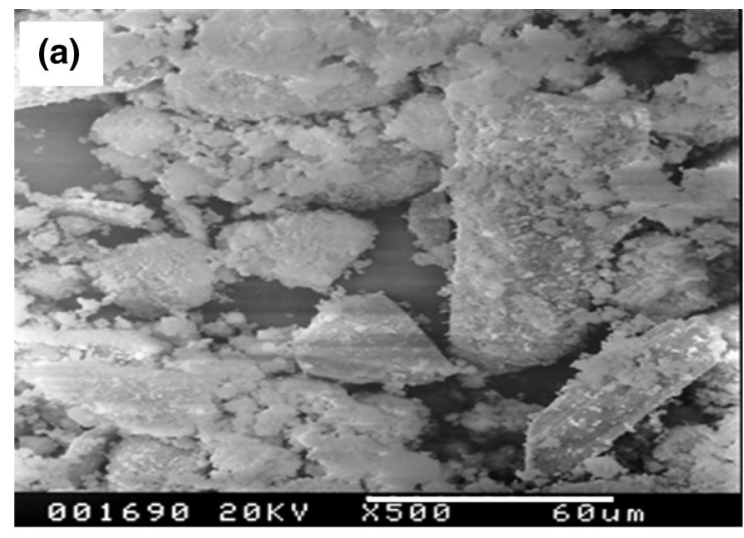

(b)

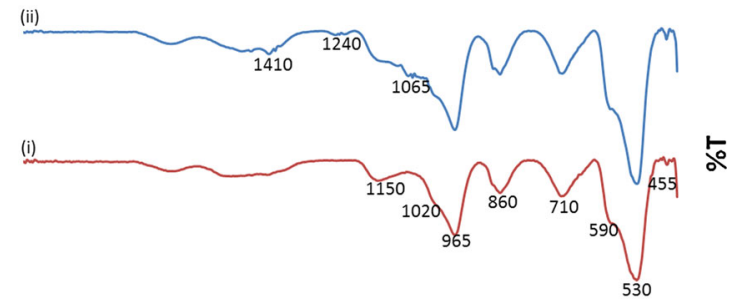

\section{$\begin{array}{lllllllll}2000 & 1800 & 1600 & 1400 & 1200 & 1000 & 800 & 600 & 400\end{array}$ Wave number $(\mathrm{cm}-1)$}

Fig. 4 a SEM image of strätlingite-gypsum-water mixture cured at $55{ }^{\circ} \mathrm{C}$; shows no significant reaction; b IR spectra of strätlingite before reaction (i); and after 70 days cure in saturated gypsum solution aged at $20^{\circ} \mathrm{C}$ (ii)

centred at $\sim 1065 \mathrm{~cm}^{-1}$ corresponds to that reported in literature for $\mathrm{S}-\mathrm{O}$ stretching vibration and $\mathrm{C}-\mathrm{O}$ associated with AFm and AFt phases $[2,3,16]$. But the absence of further absorption band which correspond to sulfate and presence of multiple bands characteristic of $\mathrm{C}-\mathrm{O}$ supports that the band centred at $\sim 1065 \mathrm{~cm}^{-1}$ is due to $\mathrm{C}-\mathrm{O}$ vibration from contaminants and that sulfate uptake has been negligible. No changes were noted in the powder X-ray pattern relative to pure strätlingite. Thus, the coexistence of gypsum and strätlingite is confirmed but no evidence indicating mutual solid solution was adduced. In view of the bulky nature of the aluminosilicate interlayer ion it seems unlikely that substitution of the smaller sulfate should leave d-spacings unaffected.

\subsubsection{Strätlingite-SO $\mathrm{S}_{4}$-AFt phase relation: $20-85{ }^{\circ} \mathrm{C}$}

The XRD pattern of the 1:1 molar mixture of strätlingite- $\mathrm{SO}_{4}$-AFt in water, after curing for 30 days (Fig. 5a), shows that strätlingite coexists with $\mathrm{SO}_{4^{-}}$ AFt at $20-85^{\circ} \mathrm{C}$. Results of the two compartment experiment corroborate previous results suggesting the compatibility of these phases (Fig. 5b).

\subsubsection{Strätlingite- $\mathrm{SO}_{4}-\mathrm{AFm}$ phase relation: $20-85{ }^{\circ} \mathrm{C}$}

The XRD pattern of the mechanical mixture of strätlingite and $\mathrm{SO}_{4}{ }^{2-} \mathrm{AFm}$ reacted for 30 days at 20-85 ${ }^{\circ} \mathrm{C}$ shows no evidence of reaction (Fig. 6b). Trace amounts of ettringite occurred but these were known to have been present in the original AFm sample (Fig. 6a). Strätlingite and $\mathrm{SO}_{4}$-AFm appear to coexist for this temperature range and duration of reaction.

\subsection{Strätlingite in the presence of carbonate: $20-85{ }^{\circ} \mathrm{C}$}

\subsubsection{Strätlingite-calcite phase relation: $20-85^{\circ} \mathrm{C}$}

The XRD pattern of the resulting solid after 4 weeks aging of the strätlingite-calcite slurry shows that the two phases are compatible under the conditions of the experiment; the presence of calcite, apparently does not affect the stability of strätlingite at $20 \pm 2,55$ and $85{ }^{\circ} \mathrm{C}$ (Fig. 7a). The two phases coexisted at the studied temperatures and the peak positions of the $\mathrm{X}$-ray reflections due to strätlingite have not been affected, suggesting, perhaps, that little or no structural substitution of $\mathrm{CO}_{3}{ }^{2-}$ has occurred in strätlingite as the peak position of the X-ray reflections due to strätlingite are unaffected. Further investigation by the two compartment experiment corroborated previous observation as the XRD pattern of strätlingite shows

Table 1 Assignment of infrared spectra data from strätlingite-gypsum relation studies; spectra shown in Fig. 4b

\begin{tabular}{llllll}
\hline IR absorption band $\left(\mathrm{cm}^{-1}\right)$ & $530 ; 590 ; 965$ & 455 & 1020 & 1150 & $710 ; 860 ; 1065 ; 1240 ; 1410$ \\
\hline Assignments of vibration & $\mathrm{Al}-\mathrm{O}$ & $\mathrm{Si}-\mathrm{O}$ bending & Si-O vibration & Si-O-Al asymmetric & $\mathrm{C}-\mathrm{O}$ \\
\hline
\end{tabular}




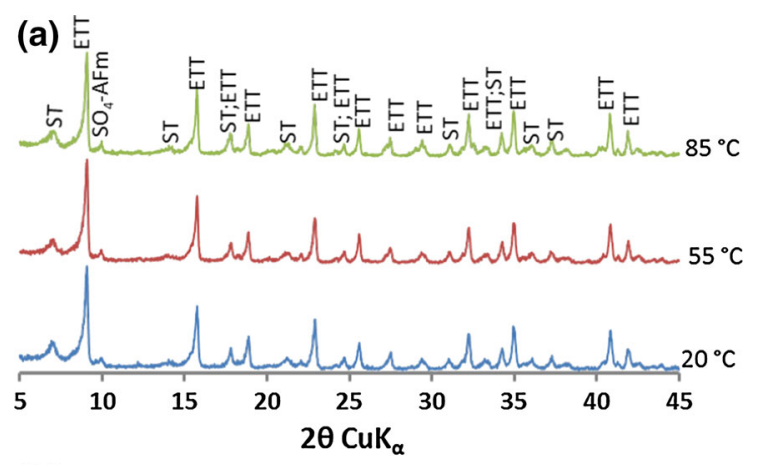

(b)

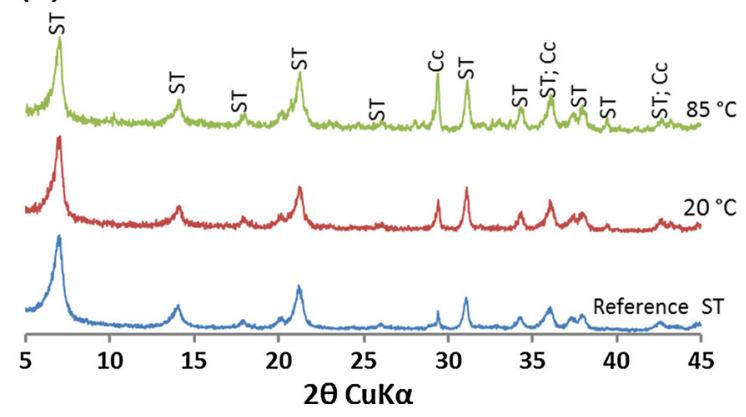

Fig. 5 XRD patterns of a 1:1 molar mixture of strätlingite$\mathrm{SO}_{4}$ - $\mathrm{AFt}$ after 30 days reaction in water; $\mathbf{b}$ strätlingite after curing for 56 days in saturated $\mathrm{SO}_{4}-\mathrm{AFt}$ solution

that strätlingite was not affected after curing in saturated calcite solution for 56 days at $20-85{ }^{\circ} \mathrm{C}$ (Fig. 7b). The minor XRD reflection at $\sim 29.3^{\circ} 2 \theta$ in the XRD pattern of starting strätlingite reactant (Fig. 7b), due to minor calcite contaminant, has become prominent after curing for 56 days in saturated calcite solution. This apparently indicates minor precipitation of calcite into the strätlingite had occurred. IR spectra (Fig. 7c (ii)) of the strätlingite sample cured in calcite solution for 56 days at $20{ }^{\circ} \mathrm{C}$ similarly show a minor absorptions at $\sim 1065, \sim 1240$ and $\sim 1400 \mathrm{~cm}^{-1}$ corresponding to $\mathrm{C}-\mathrm{O}$ vibrations of carbonate, probably associated with "AFm-type strätlingite" $[2,3,16,22]$. That indicates a minor uptake of carbonate in the form of calcite, which may have precipitated from solution and/or originating from atmospheric contamination, and like the case of sulfate has no implication for solid solution.

\subsubsection{Strätlingite-CO $\mathrm{CO}_{3}$-AFt phase relation: $20-85{ }^{\circ} \mathrm{C}$}

The XRD pattern of the 1:1 molar mixtures of strätlingite- $\mathrm{CO}_{3}$-AFt cured for 30 days (Fig. 8a) show
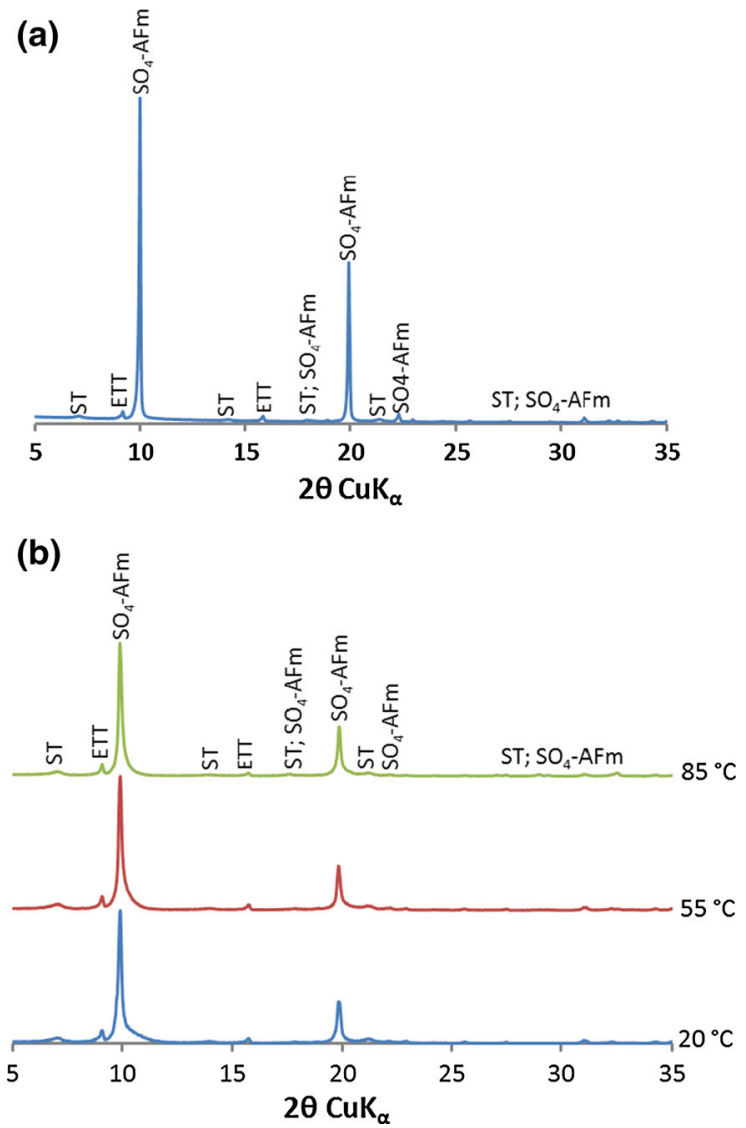

Fig. 6 Strätlingite- $\mathrm{SO}_{4}-\mathrm{AFm}$ phase relation: a raw mixture before reaction; $\mathbf{b}$ after 30 days cure at 20,55 and $85^{\circ} \mathrm{C}$ : the phases appear to coexist

that strätlingite coexists with $\mathrm{CO}_{3}-\mathrm{AFt}$ at $20 \pm 2{ }^{\circ} \mathrm{C}$. However at $55^{\circ} \mathrm{C}, \mathrm{CO}_{3}$ - $\mathrm{AFt}$ had decomposed to calcite and $\mathrm{AFm}$ but strätlingite persisted. At $85{ }^{\circ} \mathrm{C}$ where $\mathrm{CO}_{3}$-AFt had completely decomposed and strätlingite, being less stable at this temperature, reacted forming mainly siliceous hydrogarnet which coexisted with calcite and $\mathrm{C}-\mathrm{S}-\mathrm{H}$. Trace amounts of strätlingite was still detected at up to 30 days at $85^{\circ} \mathrm{C}$ but not thereafter.

It is known that in relevant systems such as limestone-blended Portland cement hydration, carbonate activity is initially conditioned by calcite, followed by $\mathrm{AFt}$ but because $\mathrm{CO}_{3}-\mathrm{AFt}$ is metastable with respect to $\mathrm{CO}_{3}-\mathrm{AFm}$ [5], $\mathrm{CO}_{3}-\mathrm{AFt}$ is not formed under these conditions, leaving the system to be buffered with respect to carbonate by calcite and $\mathrm{CO}_{3}$-AFm. Also, carbonate AFm is unstable at high temperatures and its decomposition generates high 
(a)

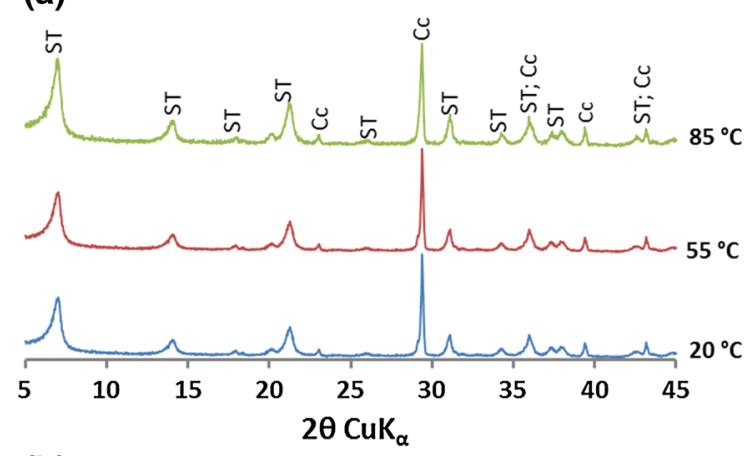

(b)

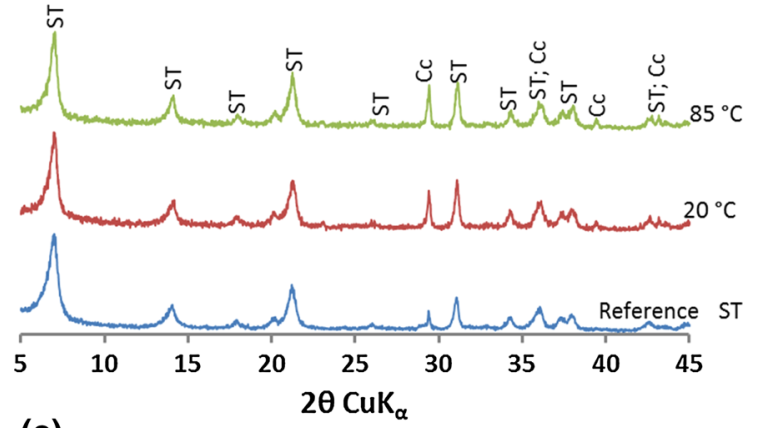

(c)

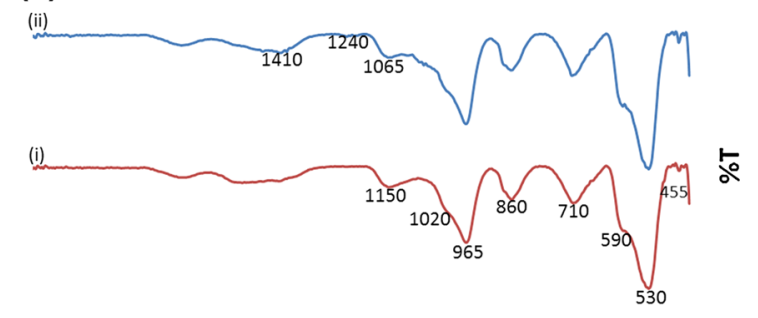

Fig. 7 XRD patterns of a 1:1 molar mixture of strätlingitecalcite after 30 days reaction in water; $\mathbf{b}$ strätlingite after curing for 56 days in saturated calcite solution; c IR spectra of strätlingite before reaction (i), and after 56 days cure in saturated calcite solution aged at $20^{\circ} \mathrm{C}$ (ii)

alumina activity which causes strätlingite to start reacting at above $55^{\circ} \mathrm{C}$ producing the more stable siliceous hydrogarnet. See also Sect. 3.2.3.

\subsubsection{Strätlingite- $\mathrm{CO}_{3}-\mathrm{AFm}$ phase relations: $20-85^{\circ} \mathrm{C}$}

The XRD pattern of the resulting solids shows that at 20 and $55^{\circ} \mathrm{C}$, strätlingite coexisted with $\mathrm{CO}_{3}-\mathrm{AFm}$, but hydrogarnet solid solution forms at $55{ }^{\circ} \mathrm{C}$ while at

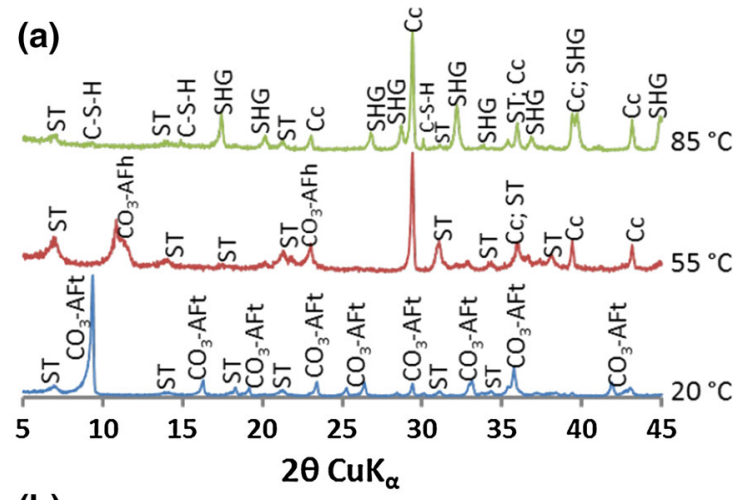

(b)

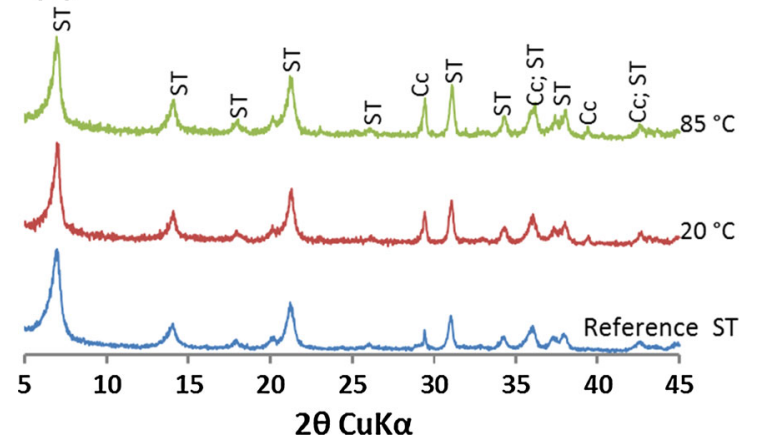

Fig. 8 XRD patterns of a 1:1 molar mixture of strätlingite$\mathrm{CO}_{3}$-AFt after 30 days reaction in water; $\mathbf{b}$ strätlingite after curing for 56 days in saturated $\mathrm{CO}_{3}-\mathrm{AFt}$ solution

$85^{\circ} \mathrm{C}$, the $\mathrm{CO}_{3}$-AFm had decomposed to mainly hydrogarnet solid solution and calcite (Fig. 9). It can be deduced that, the decomposing of $\mathrm{CO}_{3}$-AFm at high temperature increased the alumina activity in the solution, and as calcite crystallised, shift in mass balances promotes formation of hydrogarnet solid solution at temperature of $55{ }^{\circ} \mathrm{C}$ and above.

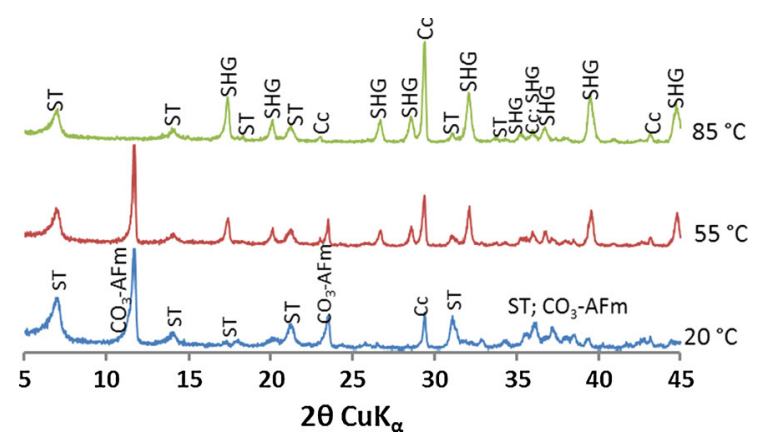

Fig. 9 Strätlingite- $\mathrm{CO}_{3}-\mathrm{AFm}$ phase relation at 20, 55 and $85{ }^{\circ} \mathrm{C}$ 
From the results, strätlingite has shown compatibility with calcite, gypsum, sulfate and carbonate AFm and AFt at temperatures below about $55^{\circ} \mathrm{C}$. Strätlingite coexistence with AFt (ettringite), has also been predicted in previous thermodynamic models [1, 4].

Described phase compatibility is not only affected by temperature but also by ion activity and time. The early stages of cement hydration, at $\sim 20{ }^{\circ} \mathrm{C}$, when solid gypsum or other form of $\mathrm{CaSO}_{4}$ is present, sulfate activity is relatively high, conditioned by gypsum, but as gypsum is consumed to form AFt, the sulfate activity is instead conditioned by the composition and solubility of the AFt phase. As more calcium and alumina react, AFt is partially converted to AFm phase and the sulfate activity at this time is now buffered by the pair AFt-AFm. For most commercial cements, this state is reached within the first $24-48 \mathrm{~h}$ of hydration. The same principles operate for limestone-blended Portland cement hydration: carbonate activity is initially conditioned by calcite, followed by $\mathrm{AFt}$ but because $\mathrm{CO}_{3}-\mathrm{AFt}$ is metastable with respect to $\mathrm{CO}_{3}-\mathrm{AFm}$ [5], $\mathrm{CO}_{3}-\mathrm{AFt}$ is not formed under these conditions, leaving the system to be buffered with respect to carbonate by calcite and $\mathrm{CO}_{3}$-AFm.

Carbonate and sulfate variants of strätlingite are not well known. However the strätlingite structure can be regarded as a potential host for at least four anions common in cement systems- $\mathrm{OH}, \mathrm{Cl}, \mathrm{SO}_{4}$ and $\mathrm{CO}_{3}$. Chloride was not included in this study but the remaining three anions were either present or potentially present. The competition for anion content will depend on $\mathrm{pH}$ as well as the thermodynamic properties of the other coexisting solid phases and the aqueous activity of the relevant anion species. Assuming an alkali free system, a complete description of the anion content in strätlingite would differ for each assemblage and would be temperature dependent: the data would take the form of a series of distribution coefficients. The present data are insufficient to quantify these coefficients and their temperature dependence but a start has been made by determining the phase assemblages. However we note that many of these assemblages condition a low aqueous activities of sulfate and carbonate (the host solids containing these ions have low solubilities and the impact of solid solution on the powder patterns of strätlingite has not been quantified. But it is not surprising that in many assemblages $\mathrm{OH}$ strätlingite predominates. This finding is not in conflict with the observation that under other conditions especially of higher species activities of sulphate and carbonate, extensive anion substitution can occur in strätlingite. Indeed, in one experiment (Fig. 7) sufficient carbonate was recorded to influence the FTIR spectra.

In the presence of $\mathrm{Mg}$, strätlingite has also been predicted to occur together with hydrotalcite-like phases and a wide range of observations supports this, for example data on systems formulated with activated calcined paper sludge, kaolinite and slag blends [6-8, $11,12]$, all of which introduce $\mathrm{Mg}$ in various ways. However, for strätlingite to form in such blended cement systems, the compositions in terms of $\mathrm{C}-\mathrm{A}-\mathrm{S}$ ratio must lie in the phase region where strätlingite is readily stable $[17,18]$.

Data reported for the coexistence of strätlingite with other phases are generic: that is the amount of phase added does not affect the phase relations. However we have controlled the activity of species such as sulfate and carbonate by using those phases which are known to occur in commercial cements: if it were forced as by adding a soluble carbonate salt, we might depart form conditions in commercial cement and the stability of phases and limits of composition altered. So when we conclude that solid solution is negligible, the conclusion is conditional. That is, it applies to the conditions of the experiment, the most important condition being what other phases are present. But the result is still generic in the sense that the amount of other phases is not crucial with respect to determining reaction direction. And we have chosen conditions which are relevant to modern commercial cements including those modified by supplementary materials. For example, strätlingite is thermally destabilised in the presence of carbonate AFm where siliceous hydrogarnet forms at $55^{\circ} \mathrm{C}$ and above. For similar reasons we avoid giving a single value for the upper stability limit of strätlingite: the exact temperature is conditional, depending on what other phases are present.

\section{Conclusions}

At the level of soluble anion concentrations found in Portland based cements, a few tens of ppm in pore fluid, sulfate and carbonate do not substitute significantly for $\mathrm{OH}$ in the strätlingite structure. Thus, while 
strätlingite is structurally an AFm type phase, it is unlike silica-free AFm members: strätlingite binds insignificant sulfate and carbonate at $\mathrm{pH} \sim 12$. Strätlingite shows compatibility with gypsum, calcite, sulfate and carbonate $\mathrm{AFm}$ and $\mathrm{AFt}$ at temperatures below about $55{ }^{\circ} \mathrm{C}$. The resistant of its structure to attack by anions is attributable to the stability of the double tetrahedral aluminosilicate interlayer. Results can safely be used to predict conditions under which strätlingite will form and persist in Portland and modified Portland cements.

Acknowledgments The TETFund Nigeria and Abia State University Uturu are acknowledged for financial support.

\section{References}

1. Atkins M, Bennett DG, Dawes AC, Glasser FP, Kindness A, Read D (1992) A thermodynamic model for blended cements. Cem Concr Res 22:497-502

2. Bensted J, Varma SP (1974) Some applications of Infrared and Raman spectroscopy in cement chemistry part 3-hydration of portland cement and its constituents. Cem Technol 5:440-450

3. Bensted J, Varma SP (1973) Studies of ettringite and its derivatives, part 4: the low-sulphate form of calcium sulphoaluminate (monosulphate). Cem Technol 4:112-115

4. Damidot D, Lothenbach B, Herfort D, Glasser FP (2011) Thermodynamics and cement science. 13th ICCC Madrid. Cem Concr Res 41:679-695

5. Damidot D, Stronach S, Kindness A, Atkins M, Glasser FP (1994) Thermodynamic investigation of the $\mathrm{CaO}-\mathrm{Al}_{2} \mathrm{O}_{3}-$ $\mathrm{CaCO}_{3}-\mathrm{H}_{2} \mathrm{O}$ closed system at $25{ }^{\circ} \mathrm{C}$ and the influence of $\mathrm{Na}_{2} \mathrm{O}$. Cem Concr Res 24:563-572

6. Fernández R, Nebreda B, De La Villa RV, García R, Frías M (2010) Mineralogical and chemical evolution of hydrated phases in the pozzolanic reaction of calcined paper sludge. Cem Concr Compos 32:775-782

7. García R, Vigil de la Villa R, Rodríguez O, Frías M (2010) Study of hydrated phases present in calcined paper sludge (metakaolinite)/saturated $\mathrm{CaO}$ dissolution system cured at $40{ }^{\circ} \mathrm{C}$ and 28 days of reaction. Mater Sci Eng A 527:3939-3941
8. García R, Vigil de la Villa R, Rodríguez O, Frías M (2009) Mineral phases formation on the pozzolan/lime/water system. Appl Clay Sci 3-4:335

9. Hidalgo López A, García Calvo JL, García Olmo J, Petit S, Alonso MC (2008) Microstructural evolution of calcium aluminate cements hydration with silica fume and fly ash additions by scanning electron microscopy, and mid and near-infrared spectroscopy. J Am Ceram Soc 91:1258-1265

10. Horgnies M, Chen JJ, Bouillon C (2013) Overview about the use of Fourier transform infrared spectroscopy to study cementitious materials. 6th Int Conf Comput Methods Exp Mater Charact 77:251-262

11. Largo OR, De La Villa RV, Jiménez RG, Gõmez BN, Frías M (2011) Lower temperature activation for kaolinite-based clay waste: evaluation of hydrated phases during the pozzolanic reaction. J Am Ceram Soc 94:1224-1229

12. Lothenbach B, Gruskovnjak A (2007) Hydration of alkaliactivated slag: thermodynamic modelling. Adv Cem Res 19:81-92

13. Matschei T (2009) Thermodynamics of Cement Hydration. PhD Thesis. University of Aberdeen

14. Matschei T, Glasser FP (2010) Temperature dependence, $0-40{ }^{\circ} \mathrm{C}$, of the mineralogy of Portland cement paste in the presence of calcium carbonate. Cem Concr Res 40:763-777

15. Matschei T, Lothenbach B, Glasser FP (2007) Thermodynamic properties of Portland cement hydrates in the system $\mathrm{CaO}-\mathrm{Al}_{2} \mathrm{O}_{3}-\mathrm{SiO}_{2}-\mathrm{CaSO}_{4}-\mathrm{CaCO}_{3}-\mathrm{H}_{2} \mathrm{O}$. Cem Concr Res 37:1379-1410

16. Mendes A, Gates WP, Sanjaya JG, Collins F (2011) NMR, XRD, IR and synchrotron NEXAFS spectrosopic sudies of OPC and OPC/slag cement paste hydrates. Mater Struct 44:1773-1791

17. Okoronkwo MU, Glasser FP (2015) The lime-aluminasilica-water system: implications for the long-term durability of cement-steel composites. In: Proceedings of 14th ICCC, Beijing

18. Okoronkwo MU (2014) Phase development in cement hydrate systems. PhD Thesis, University of Aberdeen

19. Rinaldi R, Sacerdoti M, Passaglia E (1990) Stratlingite: crystal structure, chemistry, and a reexamination of its polytype vertumnite. Eur J Miner 2:841-849

20. Shape Software (2013) ATOMS V6.4.1

21. Taylor HFW (1997) Cement chemistry. Thomas Telford Publishing Services Ltd, London

22. Trezza MA, Lavat AE (2001) Analysis of the system $3 \mathrm{CaO} \cdot \mathrm{Al}_{2} \mathrm{O}_{3}-\mathrm{CaSO}_{4} \cdot 2 \mathrm{H}_{2} \mathrm{O}-\mathrm{CaCO}_{3}-\mathrm{H}_{2} \mathrm{O}$ by FT-IR spectroscopy. Cem Concr Res 31:869-872 